\title{
Functioning of Proper Names in the English Literary Text
}

\author{
Gunel Xanlar Yunusova ${ }^{1}$
}

${ }^{1}$ Azerbaijan University of Languages

134 Rashid Behbudov Street, Baku, 370022, Azerbaijan

DOI: $10.22178 /$ pos. $70-3$

LCC Subject Category:

PE1001-1693

Received 16.04.2021

Accepted 26.05.2021

Published online 31.05.2021

Corresponding Author:

geray.80@mail.ru

(C) 2021 The Author. This article is licensed under a Creative Commons Attribution 4.0 License @ (1)

\begin{abstract}
This article discusses the functioning of proper names in a literary text. The primary attention is paid to the study of the essential functions of anthroponyms. This work will focus on studying the origin of anthroponyms and their use in a poetic text. The features of each functional style have long made it possible to contrast the literary and artistic style with everyone else in the presence of exceptional semantic complexity in the literary texts, a multi-tiered composition, and the aesthetic function of the word that organises the entire context of the work. Onomastic units are integral components of the space of a literary text; they are a connecting, constructive element of the meaningful and semantic space and structure of the text. Proper names participate in the creation of semantic multidimensionality of the text, are a means of translating the author's intention and the artistic idea of the work. The article uses descriptive and comparative linguistic methods. It is noted here that the creation of proper names is a practical process and is directly related to the mental-national thinking of the people. The scientific and methodological study of names is theoretical. The proper name in a work of art performs some artistic functions. They include identification, ensuring unity of perception, characterising a character, shaping his image and plot of work, forming subject-object relationships, spatio-temporal and compositional organisation of work, and implementing intertextual connections.
\end{abstract}

Keywords: proper names; onomastics; onym; the emotional-semantic colouring of the name.

\section{INTRODUCTION}

Proper names, namely personal names, play a central role in accumulating and transmitting cultural information, determining their exceptional value for interpreting a literary text. Proper names have attracted the attention of scientists since ancient times.

The history of onomastic lexemes' occurrence and meaning, connection with the life of society, with the worldview and beliefs of people, with the nature around us have been studied of various scientific disciplines - history, geography, ethnography, local history, psychology, literary criticism.

There is a special section in linguistics, a whole line of linguistic research devoted to names, titles, and denominations - onomastics. This scientific term is based on the Greek word "onomastike", which was translated into the Azerbaijan language in ancient times, just like "the art of giving names".

We can define proper names from this perspective as historical-cultural and spatio-temporal milestones in the ethnos' history and language. Recently, many researchers have been talking about the particular position of homonyms in the context of the artwork. It becomes evident that the study of a work is impossible without studying proper names in a text. Active consideration of this problem in the philological vein continued in the works of M. Bakhtin, Yu. Lotman, D. Likhachev, R. Chapel, M. Grimand, E. Lambert. However, for all the abundance of publications, many problems associated with artistic names are only identified. Factual material is actively collected and analysed; names are described and investigated in the artistic heritage of Russian and foreign authors, dictionaries of names are compiled in separate works and the work of the writer as a whole.

\section{RESULTS AND DISCUSSION}

The name's problem was addressed in work M. Bakhtin: "The unconsciousness of his etymon characterises the name; the roots of names do not 
belong to living languages, and their meaning cannot be felt. Deciphering the name's Greek and Hebrew roots gives monophonic and unambiguous glorifying characteristics (courageous, winner, noble). But, of course, it is not this meaning that determines the choice and the emotional-semantic colouring of the name, but the character of the saint who sanctified and canonised this name, or that person (father, grandfather, ancestor, friend, historical figure) in whose honour or memory this name is selected" [2, p. 28].

The proper names used in fiction are the object of study of poetic or literary onomastics. "The systematic nature of this space determines the organising role of onomastic space in the structure of a literary text: All this is reflected in the work of art and plays a constructive role in conveying human relations, shades of intimacy, officiality, age ratings and other characteristics. In any work, a literary character is affirmed in the reader's mind by his appearance, character traits, actions, thoughts, a peculiar speech. If this or that character was a success for the writer, then in the readers' view, all his features will be connected with one word his name. Each new name, if it appears on the pages of a work created by the hand of a true artist, and if this work is read by someone who knows the art of reading, attracts attention, is alarming, causes specific associations, creates a certain mood.

In literature, a proper name, its meaning and form, situations of its use are not random, since proper names, with the language and style of the work, occupy a special place in the system of artistic and visual means used to express author design. The appearance of naming is determined by the plot-thematic content of the work, and its leading ideas, the laws of the genre and the stylistic system of the text as a whole. Therefore, the literary onym, an essential element of the artistic structure, can actively express the content and subtext information.

It reflects an individual author's understanding of events and facts described in an imaginary world. It conveys to the reader hidden information extracted due to the name's ability to generate associative and connotative meanings. The specificity of symbolic and artistic comprehension of the word also affects the functions of proper names included in the composition of a literary work. In the literary text, onyms undergo operational restructuring. The main thing is not so much nominative; how much is a characterising function, which largely depends on the genre of the work.

The study of the proper name includes a research of the structural organisation of the onomastic space, the principles and methods of nominating the characters, the stylistic functions of the onyms, their associative relations.

All literary anthropology can be classified in terms of its origin. So, the first group consists of proper names, entirely borrowed by the writer from what already exists in the culture.

Onomastic words without any change, that is, they "are not in any way created by the author of the text, but are borrowed by him from the general cultural and linguistic arsenal" [8, p. 72].

The second group includes anthroponyms from which only the sound-graphic shell is borrowed from the onomastic lexicon already existing in the culture. The internal form of these onyms is not always speaking; often enough, it is erased, the semantics are darkened. "Each realist writer can find many semantically motivated names, surnames, names, but they never fill the entire onomastic space of a literary text, there are different types of proper names, including those indirectly motivated by the historical norms of the onomastic lexicon, the social sphere, speechusus and other reasons" [8, p.81]. In the analysis of the internal form, the original meaning of the name should be given only when the presence of a connection between it and the characteristic of the image given by the author is revealed. Such an approach is since "in work, the pre-anthropological meaning is highlighted, the semantics of the name is revived".

The third group includes anthroponyms wholly invented by the author. It seems reasonable to subdivide this group according to whether the writer uses existing common nouns of the original language, translating them into their own, or creating entirely new sound-graphic complexes. The study of stylistic onomastics, and in particular one of its most essential components, antonomasia, is due to the urgent need for a deeper understanding of the work of art. The term antonomasia is usually used to mean a trail, "consisting in the metaphorical use of a proper name to denote a person endowed with the properties of the original bearer of this name" [1]. For example, the usual surname Chervyakov in the context of the story of 
A. Chekhov "The death of an official" prompts to correlate the character with the worm.

The author must organise the context with particular skill so that the reader first thinks that Chervyakov is the most common surname, then realises that this is not just a surname, but a kind of artistic epithet he is convinced his guess is correct. Once in the world of literature, personal names become a crucial artistic tool in the onomastic system of text and all the writer's work. A. Kuharenko correctly noted that the proper name, entering the work, "comes out of it semantically enriched and acts as a signal that excites an extensive complex of associative meanings. They can be considered a local semantic structure, which is assigned to a given name as its own" [9, p. 124]. Thus, the onomastic vocabulary of a work of art occupies a special place in the verbal palette. It appears in each writer as a noticeable expressive means, a bright sign of style.

Researchers of this problem distinguish various functions of personal names in a literary text, such as spatio-temporal, characterising, comparatively descriptive, symbolic. Performing a spatio-temporal function, personal names, along with other linguistic means of expression, are objects in the space of a literary text and thus relate the secondary reality of a literary text to objective reality.

Firstly, such a correlation allows to set the spatiotemporal coordinates of the world's image revealed in the literary text. Secondly, to create for the reader an "illusion" of the reality of the events described in the text. Here, each personal name is a link that connects objectively existing reality with the author's fiction, which allows you to "revive" the literary text.

Personal names are capable of specifying a spatiotemporal framework rather precisely and creating a unique atmosphere of the reality of events, maintaining a sense of national identity and colour thanks to the nationally-labelled component present in their meaning, as well as background information. Due to the presence in the text of personal names that evoke associations in the reader's mind with the culture, history, social structure of society, the author's vision of the world is revealed - for example, the works F. Durrenmatt reflecting the acute social problems of the country and exposing hypocrisy.

A. Superanskaya considers that proper names in literary texts have two specific features: "Firstly, their denotations are constructed based on the experience of an artist, writer, musician, but do not necessarily exist in reality; secondly, they are created according to models of names of real or unreal objects, taking into account their belonging to a certain semantic field" [12, p. 148].

Another onomast, Yu. Karpenko identifies five aspects of a proper name [7, p. 34-40]:

1) Secondary literary onomastics is based on nationwide onomastics, which the writer cannot abstract from. That is why literary onomastics is a "subjective reflection of the objective". Although the writer modifies onomastic models, he does not violate the principle of recognition.

2) Different causation of the appearance of literary onomastics and real onomastics: the genre and style of the text, as well as the design and preferences of the author, are determining factors for literary onomastics and for real ones, these will be social and historical patterns).

3) The difference between the functions of proper names in every day (the primary function is differentiating) and in artistic speech (the primary function is stylistic);

4) Literary onomastics is a fact of speech: a proper name goes into a language only when it becomes a symbol name/precedent name. In this case, the information content of the proper name is hypertrophied, and it approaches the appeals;

5) The presence of a literary and artistic work of the title, a particular type of proper names: the title in the classification of proper names are chrematonyms - the names of individual objects. At the same time, they are materially homogeneous with the designated objects. The titles most clearly combine information richness and appraisal.

The purpose of a proper name in the text is that they are an essential constructive and connecting element of the semantic space and the external organisation of the text. The writer, by chance, does not create the onomastic space of a novel or story; it carries the author's intention and helps to reveal it. The text-forming role of a proper name is formed based on its functional, sociocultural and systematic features. An essential role for the disclosure of the author's intention through proper names, their motivation also plays. "Onomastic text analysis by decoding the semantic content of onyms leads to an understanding of the system of images, the author's intention, the literary text as a whole" [37]. Thus, proper names endowed with 
wealth and various connotations and associative connections are integral elements of a work of art, updating much extralinguistic information. "Speaking about the artistic semantics of proper names, I want to note that each unit of a work of art contributes to the construction of the figurative semantic structure of a work", - writes T. Bakastova [1].

In the process of obtaining new connotations within a work, proper names undergo a "semantic increment", form their semantic structure, as a result of which there arises an artistic-lexical (individually-artistic) meaning of the word, which significantly differs from its general linguistic meaning. This is especially characteristic of the socalled symbolic names, which have turned into phenomena of a national or world culture due to frequent use in "cultural" texts. This happens because proper names enter into connection with the surrounding context and acquire new connections in it. Contextual connotations can transform the reader's perception of proper names. The accumulation of various kinds of connotations and semantic components, coming from associations in the text and behind the text, 0 . Fonyakova calls "suggestiveness" [5, p. 32], and V. Kalinkin uses the term for the development of proper names throughout an artwork "Poetonimogenesis": therefore, the connotations of a work of art, even connotative ones, except for the usual connotations, always have a connotative sphere connected by the test of the work. It is an integral part of the semantics of literary onym [6, p. 181]. Therefore, the process of accumulating information goes on continuously, in parallel with the development of the plot. The name "absorbs" all the information associated with it. Thus, proper names fully realise their entire volume of meaning acquired in art only based on the whole text. It does not matter if it is about real names, names that make up the cultural foundation of a particular nation (names belong to this category characters of famous books, mythonyms, names of cultural figures and the names of works of art), or of fictitious names invented by the writer. "Throughout the work of art, some names go from the first mention of the object of the nomination to the accumulation of all information about it - there is a natural increase, an increase in the amount of information contained in the name" [6, p. 182].

Friedhelm Debus distinguishes the following types of proper names in the literary text [4, p. 5773]:
1.Talking names are those names, lexical and (possibly) the etymological significance of which is of characteristic importance. These names are most often nicknames since they are based on a characteristic feature of the designated object. They were used in literature in the ancient period. Their use experienced a new flourishing in the era of classicism, but they are often found in works of the era of realism. Their semantic clarity does not always lie on the surface, but it is pretty easy to detect with a more detailed literary analysis. The subtype of these names is symbol names.

2. Classifying names are those names that determine the affiliation of the named object to a particular group according to religious, national, social or other characteristics relevant to the given work. This type of name began to appear more often in texts from the 17th century. The distinction of one name from a group of others in any way can be of great importance.

3. Substitution - this is a technique whose harmony, the dissonance is essential for artistic content works. In this case, a considerable role is played by subjective perception.

4. "Real" names are those names that mean natural objects and real personalities, historical or modern, or the names of literary heroes that the author "incorporates" into his work. Thanks to formal identity, a sense of the reality of the fictitious world is achieved. Sometimes such names may be slightly modified to obtain the effect of "alienation" or language game.

Proper names were analysed in detail in the functional aspect. Researchers were able to detect common manifestations of some of the functional properties of proper names. The fact is that having differences in terms of the specifics of use in fiction and non-fiction texts, proper names perform somewhat different functions in literary works than in other areas of use. I. Maslova concludes that toponyms and chrononyms usually form a local-temporal unity in a workspace. "In this case, they convey the outline of the events described, form the background of the narrative," she writes. Proper names of other categories are most often used by the author optionally, with the aim of artistic detail narrative, maximising credibility and credibility [10, p. 2].

The author also attempted to characterise the functions of proper names in fiction Bondaletov. He singled out nominative, ideological, characterising, aesthetic and symbolic functions [3, p. 63]. 


\section{CONCLUSION}

Proper names, namely personal names, play a central role in accumulating and transmitting cultural information, determining their exceptional importance for interpreting a literary text. The nature and amount of additional information provided by the name depend on its name and its function within the context.

\section{REFERENCES}

1. Bakastova, T. (1987). Semantizacija imeni sobstvennogo v celom hudozhestvennom tekste: na materiale anglijskogo jazyka [The semantization of the proper name in the whole literary text (on the material of English)] (Doctoral thesis). Odessa (in Russian) [Бакастова, Т. (1987). Семантизация имени собственного в целом художественном тексте: на материале английского языка (Кандидатская диссертация). Одесса].

2. Bakhtin, M. (2000). Jepos i roman [Epic and novel]. Saint-Petersburg: Azbuka (in Russian) [Бахтин, М. (2000). Эпос и роман. Санкт-Петербург: Азбука].

3. Bondaletov, V.D. (1983). Russkaja onomastika [Russian onomastics]. Moscow: Prosveshhenie (in Russian) [Бондалетов, В. (1983). Русская ономастика. Москва: Просвещение].

4. Debus, F. (2002). Namen in literarischen Werken: (Er-)Findung - Form - Funktion. Stuttgart: Steiner.

5. Fonyakova, O. (1990). Imja sobstvennoe $v$ khudojestvennom tekste [Proper name in literary text]. Leningrad: LGU (in Russian)

[Фонякова, О. (1990). Имя собственное в художественном тексте. Ленинград: ЛГУ].

6. Kalinkin, V. (1999). Poetika onima [The poetics of onyme]. Donetsk: Jugo-Vostok (in Russian) [Калинкин, В. (1999). Поэтика онима. Донецк: Юго-Восток].

7. Karpenko, Yu. (1986). Imja sobstvennoe v khudodzhestvennoj literature [Proper name in fiction]. Filologicheskie nauki, 4, 34-40 (in Russian)

[Карпенко, Ю. (1986). Имя собственное в художественной литературе. Филологические науки, 4, 34-40].

8. Kubryakova, Ye. (2001). 0 tekste I kriterijakh eqo opredelenija [About the text and the criteria for its definition]. In Tekst. Struktura i semantika (Vol. 1, pp. 72-81). Moscow: n. d. (in Russian). [Кубрякова, Е. (2001). О тексте и критериях его определения. В Текст. Структура и семантика (Т. 1, с. 72-81). Москва: $\mathrm{n}$.d.].

9. Kuharenko, V.A. (1988). Interpretatsija teksta [Interpretation of the text]. Moscow: Prosveshhenie (in Russian)

[Кухаренко, В. (1988). Интерпретация текста. Москва: Просвещение].

10. Maslova (Voronova), I. (2000). Tekstoobrazujushhaja funkcija literaturnyh imen sobstvennyh (na materiale prozaicheskih proizvedenij $X I X-X X v v$.) [The text-forming function of literary proper names (based on the material of prose works of the 19th-20th centuries)] (Doctoral thesis). Volgograd (in Russian)

[Маслова (Воронова), И. (2000). Текстообразующая функция литературных имен собственных (на материале прозаических произведений XIX-XX вв.) (Кандидатская диссертация). Волгоград].

11. Mikhailov, V. (1984). Rol onomastichekoj eksiki v strukturno-semanticheskoj orqanizatsii khudodzhestvennoqo teksta [The role of onomastic vocabulary in the structural-semantic organization of a literary text]. In Russkaja onomastika (pp. 101-108). Odessa: Izdatel'stvo Odesskogo universiteta (in Russian)

[Михайлов, В. (1984). Роль ономастической лексики в структурно-семантической организации художественного текста. В Русская ономастика (с. 101-108). Одесса: Издательство Одесского университета]. 
12. Superanskaya, A. (1973). Obshaja teorija imeni sobstvennoqo [The general theory of the proper name]. Moscow: Nauka (in Russian)

[Суперанская, А. (1973). Общая теория имени собственного. Москва: Наука]. 